Original Article

\title{
Ecological impacts of climate change on the snow leopard (Panthera unica) in South Asia
}

\author{
Impactos ecológicos da mudança climática no leopardo-da-neve (Panthera uncia) no \\ sul da Ásia
}

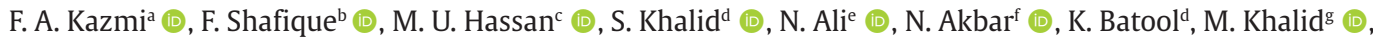 \\ S. Khawaja ${ }^{\text {h }}$ (D)
}

a Norwegian University of Life Sciences, Faculty of Environmental Sciences and Natural Resource Management, Department of Ecology, Aas, Norway ${ }^{\mathrm{b}}$ University of Sheffield, Department of Biomedical Science, Sheffield, United Kingdom

c University of Sheffield, Department of Molecular Biology and Biotechnology, Sheffield, United Kingdom

¿University of Azad Jammu and Kashmir, Department of Zoology, Muzaffarabad, Pakistan

e Abbottabad University of Science and Technology, Department of Microbiology, Abbottabad, Pakistan

${ }^{\mathrm{f}}$ Hazara University Mansehra, Centre of Human Genetics, Hazara, Pakistan

${ }^{g}$ Women University of Azad Kashmir, Department of Biotechnology, Bagh Azad Kashmir, Pakistan

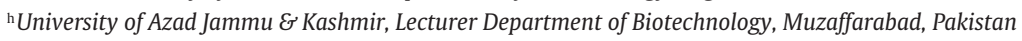

\begin{abstract}
Snow leopard (Panthera unica) is a felid which lives in the highly rugged areas of alpine regions in different mountain ranges of South and Central Asia. This solitary animal needs large spaces for its ranges but due to climate change and relatively faster rate of global warming in South Asian mountain ranges, its habitat is going to shrink and fragment by tree-line shifts and change in hydrology of the area. Vegetative modification of montane flora and competition with domestic goats will create its prey's population to decline along with a chance of a direct conflict and competition with the common leopard. Common leopard being more adaptable, grouped, and larger in size can be a significant stressor for a smaller and solitary snow leopard. Habitat would shrink, and snow leopard can possibly move upslope or northward to central Asian ranges and their predicted migratory patterns are unknown.
\end{abstract}

Keywords: snow leopard, South Asia, Himalaya, Karakorum, climate change, habitat loss.

\begin{abstract}
Resumo
O leopardo-das-neves (Panthera uncia) é um felídeo que vive nas áreas altamente acidentadas das regiões alpinas, em diferentes cadeias de montanhas do sul e do centro da Ásia. A revisão atual tem o objetivo de abordar a questão da possível perda de hábitat do leopardo da neve em razão da interferência humana nas montanhas do sul e do centro da Ásia. Esse animal solitário precisa de grandes espaços para suas faixas, mas, devido às mudanças climáticas e à taxa relativamente mais rápida de aquecimento global nas cadeias montanhosas do sul da Ásia, seu hábitat vai encolher e fragmentar-se por mudanças nas linhas de árvores e na hidrologia da área. Este artigo teve o objetivo de rever vários estudos sobre os impactos das mudanças climáticas em um futuro próximo e distante sobre os hábitats do leopardo-da-neve. O estudo revelou que a modificação vegetativa da flora da montanha e a competição com cabras domésticas poderiam ocasionar na diminuição da população de suas presas, com a chance de um conflito direto e competição com leopardo comum. Leopardo comum sendo mais adaptável, agrupado e maior em tamanho pode ser um estressor significativo para um leopardo-da-neve menor e solitário. Conclusão: devido ao encolhimento do hábitat, o leopardo-da-neve pode, possivelmente, mover-se para cima ou para o norte, para faixas da Ásia Central com padrões migratórios não previstos.
\end{abstract}

Palavras-chave: leopardo-da-neve, Sul da Ásia, Himalaia, Karakorum, mudanças climáticas; perda de hábitat.

\section{Introduction}

The great age of mammals in the Himalayas need not be over unless we permit it to be. For epochs to come the peaks will still pierce the lonely vistas, but when the last snow leopard has stalked among the crags and the last markhor has stood on a promontory, his ruff waving int the breeze, a spark of life will have gone, turning the mountains into stones of silence. (Schaller, 1982).

With these lines Schaller started his book Stones of Silence, in which he admits the importance of life in the

*e-mail: fshafique1@sheffield.ac.uk

Received: June 28, 2020 - Accepted: August 24, 2020 
heights that would be empty if conservation is ignored. This view is rather literary but there are more scientific reasons to conserve the keystone species of high South Asian mountains.

Snow leopard is member of genus Panthera of Felidae family. It is whitish-grey solitary cat with dark grey spots on its body (McCarthy and Chapron, 2003) thus creating a camouflage in its habitat. It is more closely related to tiger, Panthera tigris (Valentová, 2017) but unlike tigers it is unable to roar due to the absence of fibro elastic tissues in vocal fold (Peters, 1980). Snow leopard is also listed as endangered species by IUCN since 1988 and still it exists in the list (Jackson et al., 2008).

Snow leopard lives in highly rugged and steep areas $\left(>40^{\circ}\right)$ of alpine and sub alpine regions which lack vegetation and have cliffs and ridges around (Jackson and Ahlborn, 1989). In south Asian ranges it is found in Himalaya, Karakorum and Hindukush, also in high lands of central Asia like Pamir, Gobi and up to Russia (McCarthy and Chapron, 2003). In South Asian countries it occurs in Pakistan, Nepal, Bhutan, Afghanistan and India with highest area of habitat in Pakistan (Hussain, 2003) which is $80000 \mathrm{~km}^{2}$ followed by India (Chundawat et al., 1988) $75000 \mathrm{~km}^{2}$ but population-wise it occurs more in Nepal with estimated population of 300-500 (Jackson and Ahlborn, 1989) followed by India with estimated population of 200-600 (Fox et al., 1988; Chundawat et al., 1988; Bhatnagar et al., 2016) and Pakistan with 200-420 (Hussain, 2003; Schaller, 1982; Valentová, 2017).

Snow leopard prefers ranging between $4500 \mathrm{~m}$ elevation to $5800 \mathrm{~m}$ in Himalayan and Karakorum mountains (McCarthy and Chapron, 2003), usually these elevations lie above the tree line. Most of these areas are uninhabited by humans and are very remote in mountains and valleys. In Pakistan it can descent to $1500 \mathrm{~m}$ during winters (Roberts, 1977) which is the elevation close to human settlements and is forested and vegetated, but mostly it prefers to be in rough rocky areas with steep and unreachable ridges.

The very Himalayan region inhabited by Snow leopard is considered to be the most vulnerable region to climate change (Shrestha et al., 2012). Global warming is also hitting the area by increasing the annual mean temperature 3 times faster than the global mean figures (Xu et al., 2009). Glacial melting is another issue which is changing the hydrology of the greater Himalayas along with the carbon mass of soil and change in vegetative properties (Yao et al., 2004; Telwala et al., 2013).

\section{Impacts of Climate Change}

Climate change is affecting biodiversity worldwide by modifying the habitat (Xu et al., 2009; Thomas et al., 2004). Nearly all types of habitat from wetland to alpine are under threat in current and predicted scenarios (Segan et al., 2016). Habitat degradation and fragmentation are the leading causes of confinement of species resulting in to poor reproductive success, extinction, loss of genetic variation due to immobility and dispersal (Fischer and Lindenmayer, 2007). Climate change makes populations more distant thus limiting the chances of intra range movements (Williams et al., 2007) which affects their genetic diversity. We have discussed some major factors which are a potential threat to snow leopard's survival in South Asia.

\subsection{Global warming}

Since 1975 to 2005 global mean surface temperature has increased by $0.6{ }^{\circ} \mathrm{C}$, meanwhile in the same time span mean temperature of Himalayas has risen by $1.5{ }^{\circ} \mathrm{C}\left(0.06{ }^{\circ} \mathrm{C}\right.$ per year and counting) which is more than the global mean for the whole $20^{\text {th }}$ century $\left(0.8^{\circ} \mathrm{C}\right)$ (Shrestha et al., 2012) and this increase is same in Hindukush-Himalayan region (Xu et al., 2009) which also happens to be the habitat of snow leopard. Climate warming for extended periods can enhance the chances of expansion of many infectious diseases (Ostfeld and Brunner, 2015), especially by favoring the survival of vectors (Wu et al., 2016). This also happens with contagious diseases like scabies which is affecting the blue sheep in Karakorum and Himalayas of Pakistan and this sheep is major source of food for snow leopard (McCarthy and Chapron, 2003; Dagleish et al., 2007). Snow leopards can face consequences due to scabies in its major prey because there have been many mortalities due to this disease in Pakistan (Dagleish et al., 2007). This disease is a potential threat to snow leopards' survival in India and Pakistan. Also, the increasing temperatures are making the glacial melting very fast in Himalayas (Xu et al., 2009), therefore passing some steep and unreachable valleys would become easier for trophy and illegal hunters, this would definitely disturb the solitary habitat of snow leopard and decrease their population too. Moreover, global warming is also affecting the production of montane flora in alpine region due to its high sensitivity to temperature (Telwala et al., 2013), this montane flora is food of blue sheep and other ungulates residing the region, which are prey to snow leopard. Any change in vegetative behavior of alpine region would affect the food chain, since snow leopard is the top predator and keystone specie it will face consequences (McCarthy and Chapron, 2003).

\subsection{Tree line shift and interspecific conflict}

Snow leopard needs terrain and steep rugged ridges for its hiding, hunting and thermal refuge in alpine region (Jackson and Ahlborn, 1984) which suits its adaptability of camouflage in that specific area (Schaller, 1977). Climate change has induced the altitudinal shift of vegetation especially trees in alpine region (Telwala et al., 2013). That means the habitat for snow leopard is shrinking continuously and in case of South Asia, shifting northwards (Forrest et al., 2012). Since snow leopard is extremely solitary (Jackson and Ahlborn, 1984) it needs its space undisturbed, and the density of snow leopard was found very low in Chitral, Pakistan $\left(0.15 / 100 \mathrm{~km}^{2}\right)$ according to (Schaller, 1976). But when tree line shift occurs in some particular region the common Asian leopard (Panthera pardus) which is a near-threatened specie, will also start roaming in the area or range which used to be snow leopard's and since spatial avoidance is the best possible strategy for two carnivores of same class to coexist in a 
habitat (Lovari et al., 2013), two carnivores cats of same size not only can compete each other in food resources but also can kill the litter or the individual of the opposite specie (Donadio and Buskirk, 2006). This results in extreme behavioral change in the specie which would be the victim in this regard (Hayward and Slotow, 2009). Since common leopard is highly adaptable to different ecosystems as compared to the snow leopard and the size and morphology is quite comparable, there is a great chance of competition in case of geographical overlap (Lovari et al., 2013).

Although common leopard inhabits in wide range areas from plains and densely vegetated forests (Nowak and Paradiso, 1991) to the proximity to the human settlements (Athreya et al., 2013) and snow leopard likes to live and hunt in open areas with less vegetation (McCarthy and Chapron, 2003). In the place where they share a close neighborhood there is a chance of competition between these two cats since there is seen a significant overlap in the prey choice in the area where these two cats are living in sympatry of $640 \mathrm{~m}$ of elevation according to (Lovari et al., 2013). Common leopard can prey on the wide range of animals from wild to domestic (Akrim et al., 2018) and of a wide size range, that can limit the occurrence of large animals which would be overlapping with snow leopard prey strategy.

There is no study reporting the interspecific violence between snow leopard and common leopard but due to dietary overlap and a close morphological resemblance, in other words due to very less difference in body size of both cats there is a chance of conflict (Donadio and Buskirk, 2006) as both cats will consider each other a severe threat. Relatively bigger common leopard is more adaptable and superior predator as compared to smaller snow leopard (Lovari et al., 2013) so if they are considered in the model suggested by (Palomares and Caro, 1999) which says that solitary species cannot kill larger carnivore and snow leopard being victim in this case would either get limited to an undisturbed habitat, changing the prey type which would be in case shifting from a common to a less common prey, or changing the time of hunting activity (Johnson et al., 1996) and all of this would reduce the fitness of snow leopard, and make it more vulnerable.

Even the Tibetan wolf (Canis lupus) which has been coexisting with the snow leopard in many areas is also found to be a potential competitor in case of the shrinkage of habitat since a study reveals that during the harsh climate snow leopard and the wolf had to consider the domestic prey and it overlapped in most areas (Bocci et al., 2017). Wolf being a pack animal targets most of the domestic species and the species of the large size including the horse (Subba, 2012) this overlaps the snow leopard's prey strategy and in competition a solitary snow leopard will face difficulty with the Tibetan wolf pack.

\section{Projection Models}

\subsection{General distribution model}

According to a study which presented snow leopard habitat model for 2070 and used Representative Concentration Pathways (RCP); which is the scenario assessment model integrated by all the major factors of climate change including emissions, land-use change and concentration data, and this is used to predict the potential possibilities in near future (Van Vuuren et al., 2011). In all four pathways scenarios different levels of projected emissions and factors would end up with different concentrations and radiative forcing, the highest-level trajectory is RCP8.5 while lowest is RCP2.6 (Van Vuuren et al., 2011) as shown in Table 1. According to all these scenarios snow leopard habitat will significantly reduce in South Asia especially in Nepal and Bhutan (Li et al., 2016). It is also predicted that an upslope and northward shift of snow leopard's habitat in Nepal and Bhutan will occur while the habitat in India would be shrunk and fragmented instead (Forrest et al., 2012).

As discussed earlier, most of the snow leopard population is distributed in Nepal, so it is evident that this population will be the one being affected more than ever in coming years even for the lowest RCP the habitat will shrink by $28 \%$. Steppes of Tibetan plateau due to the climatic stability are considered to be the refuge for the snow leopard of Nepal and Bhutan (Li et al., 2016).

\subsection{Distribution Model of Predator and Prey}

According to another study by (Aryal et al., 2016) the models aggregated for the distribution of snow leopard and its main prey i.e. blue sheep estimate that the most influencing factor which can significantly affect the distribution of predator and prey is annual mean temperature which contributes $85 \%$ of the model, which is

Table 1. Estimates of snow leopard's habitat (km2) in RCP trajectories up to 2070 with respect to current.

\begin{tabular}{lcccrr}
\hline \multicolumn{5}{c}{ Year 2070 } \\
\hline Country & Current & RCP2.6 & RCP4.5 & RCP6.0 & RCP8.5 \\
Afghanistan & 190,839 & $165,741(-13 \%)$ & $158,107(-17 \%)$ & $147,770(-23 \%)$ & $133,431(-30 \%)$ \\
Bhutan & 8853 & $5427(-39 \%)$ & $3530(-60 \%)$ & $3682(-58 \%)$ & $1285(-85 \%)$ \\
India & 98,718 & $97,167(-2 \%)$ & $92,402(-6 \%)$ & $87,991(-11 \%)$ & $81,920(-18 \%)$ \\
Nepal & 19,945 & $14,440(-28 \%)$ & $10,496(-47 \%)$ & $10,185(-49 \%)$ & $3516(-82 \%)$ \\
Pakistan & 94,670 & $91,344(-2 \%)$ & $90,253(-5 \%)$ & $89,126(-6 \%)$ & $86,325(-9 \%)$ \\
\hline
\end{tabular}

Data source (Li et al., 2016). 
followed by precipitation mean and land cover. According to this study the habitat with and without the prey for snow leopard in Nepal will shrink in coming years.

\section{Conclusion}

Climate change is expected to have more severe impacts in Himalayan and Hindukush ranges as compared to the rest of the world. Due to habitat shrinking and tree line shifts the snow leopard will face competition with common leopard, habitat disturbance, prey shortage and conflict with human which has already started in most areas resulting into retaliatory killings. Nepal is the country which will face significant decrease in the habitat areas in coming decades as compared to Pakistan and India (Li et al., 2016). There is also a chance of upslope and northward movement of snow leopard to find refuge. For such movements and impacts on migratory behaviors we need more studies to predict this future distribution of snow leopards.

\section{Acknowledgement}

We thank all our colleagues at Norwegian University of Life Sciences, Aas, Norway, University of Sheffield, UK and University of Azad Jammu and Kashmir Muzaffarabad, Pakistan who helped collecting the studies and came up with this review article.

\section{References}

AKRIM, F., MAHMOOD, T., NADEEM, M.S., ANDLEEB, S. and QASIM, S., 2018. Spatial distribution and dietary niche breadth of the leopard Panthera pardus (Carnivora: Felidae) in the northeastern Himalayan region of Pakistan. Turkish Journal of Zoology, vol. 42, no. 5, pp. 585-595. http://dx.doi. org/10.3906/zoo-1803-2.

ARYAL, A., SHRESTHA, U.B., JI, W., ALE, S.B., SHRESTHA, S., INGTY, T., MARASENI, T., COCKFIELD, G. and RAUBENHEIMER, D., 2016. Predicting the distributions of predator (snow leopard) and prey (blue sheep) under climate change in the Himalaya. Ecology and Evolution, vol. 6, no. 12, pp. 4065-4075. http:// dx.doi.org/10.1002/ece3.2196. PMid:27516864.

ATHREYA, V., ODDEN, M., LINNELL, J.D., KRISHNASWAMY, J. and KARANTH, U., 2013. Big cats in our backyards: persistence of large carnivores in a human dominated landscape in India. PLoS One, vol. 8, no. 3, pp. e57872. http://dx.doi.org/10.1371/ journal.pone.0057872. PMid:23483933.

BHATNAGAR, Y.V., MATHUR, V.B., SATHYAKUMAR, S., GHOSHAL, A., SHARMA, R.K., BIJOOR, A., RAGHUNATH, R., TIMBADIA, R. and LAL, P. 2016. South Asia: India. In T.M. MCCARTHY and D.P. MALLON, eds. Snow Leopards. New York: Elsevier.

BOCCI, A., LOVARI, S., KHAN, M.Z. and MORI, E., 2017. Sympatric snow leopards and Tibetan wolves: coexistence of large carnivores with human-driven potential competition. European Journal of Wildlife Research, vol. 63, no. 6, pp. 92. http://dx.doi. org/10.1007/s10344-017-1151-0.

CHUNDAWAT, R., RODGERS, W. and PANWAR, H., 1988. Status report on snow leopard in India. In: Proceedings of the Fifth International Snow Leopard Symposium, October, Srinagar, IN.
Seattle, Washington: International Snow Leopard Trust and Wildlife Institute of India, pp. 113-120.

DAGLEISH, M., ALI, Q., POWELL, R., BUTZ, D. and WOODFORD, M., 2007. Fatal Sarcoptes scabiei infection of blue sheep (Pseudois nayaur) in Pakistan. Journal of Wildlife Diseases, vol. 43, no. 3, pp. 512-517. http://dx.doi.org/10.7589/0090-3558-43.3.512. PMid:17699091.

DONADIO, E. and BUSKIRK, S.W., 2006. Diet, morphology, and interspecific killing in Carnivora. American Naturalist, vol. 167, no. 4, pp. 524-536. http://dx.doi.org/10.1086/501033. PMid: 16670995.

FISCHER, J. and LINDENMAYER, D.B., 2007. Landscape modification and habitat fragmentation: a synthesis. Global Ecology and Biogeography, vol. 16, no. 3, pp. 265-280. http://dx.doi. org/10.1111/j.1466-8238.2007.00287.x.

FORREST, J.L., WIKRAMANAYAKE, E., SHRESTHA, R., AREENDRAN, G., GYELTSHEN, K., MAHESHWARI, A., MAZUMDAR, S., NAIDOO, R., THAPA, G.J. and THAPA, K., 2012. Conservation and climate change: assessing the vulnerability of snow leopard habitat to treeline shift in the Himalaya. Biological Conservation, vol. 150, no. 1, pp. 129-135. http://dx.doi.org/10.1016/j.biocon.2012.03.001.

FOX, J., SINHA, S., CHUNDAWAT, R. and DAS, P. A field survey of snow leopard presence and habitat use in northwestern India. In: Proceedings of the Fifth International Snow Leopard Symposium. International Snow Leopard Trust and Wildlife Institute of India, Seattle, Washington, 1988, pp. 99-111.

HAYWARD, M.W. and SLOTOW, R., 2009. Temporal partitioning of activity in large African carnivores: tests of multiple hypotheses. African Journal of Wildlife Research, vol. 39, no. 2, pp. 109-126. http://dx.doi.org/10.3957/056.039.0207.

HUSSAIN, S., 2003. The status of the snow leopard in Pakistan and its conflict with local farmers. Oryx, vol. 37, no. 01, pp. 26-33. http://dx.doi.org/10.1017/S0030605303000085.

JACKSON, R. and AHLBORN, G., 1984. Preliminary habitat suitability model for the snow leopard Panthera unica in west Nepal. International Pedigree Book of Snow Leopards, vol. 4, pp. 43-52.

JACKSON, R. and AHLBORN, G., 1989. Snow leopards (Panthera unica) in Nepal: home range and movements. National Geographic Research, vol. 5, pp. 161-175.

JACKSON, R., MALLON, D. \& MCCARTHY, T., 2008 [viewed 05 April 2016]. Panthera unica. The IUCN Red List of Threatened Species. Available from: http://www.iucnredlist.org/details/15957/0

JOHNSON, W., FULLER, T. \& FRANKLIN, W., 1996. Sympatry in canids: a review and assessment. Carnivore Behavior, Ecology, and Evolution, vol. 2, pp. 189-218.

LI, J., MCCARTHY, T.M., WANG, H., WECKWORTH, B.V., SCHALLER, G.B., MISHRA, C., LU, Z. and BEISSINGER, S.R., 2016. Climate refugia of snow leopards in High Asia. Biological Conservation, vol. 203, pp. 188-196. http://dx.doi.org/10.1016/j.biocon.2016.09.026.

LOVARI, S., VENTIMIGLIA, M. and MINDER, I., 2013. Food habits of two leopard species, competition, climate change and upper treeline: a way to the decrease of an endangered species? Ethology Ecology and Evolution, vol. 25, no. 4, pp. 305-318. http://dx.doi.org/10.1080/03949370.2013.806362.

MCCARTHY, T.M. and CHAPRON, G., 2003. Snow leopard survival strategy. Seattle, USA: International Snow Leopard Trust and Snow Leopard Network, p. 105.

NOWAK, R.M. and PARADISO, J., 1991. Walker's mammals ofthe world. Baltimore: Johns Hopkins Univ, Press, 1629 p.

OSTFELD, R.S. and BRUNNER, J.L., 2015. Climate change and Ixodes tick-borne diseases of humans. Philosophical Transactions of the Royal Society of London. Series B, Biological Sciences, vol. 370, no. 
1665, pp. 20140051. http://dx.doi.org/10.1098/rstb.2014.0051. PMid:25688022.

PALOMARES, F. and CARO, T.M., 1999. Interspecific killing among mammalian carnivores. American Naturalist, vol. 153, no. 5, pp. 492-508. http://dx.doi.org/10.1086/303189. PMid:29578790.

PETERS, G., 1980. The vocal repertoire of the snow leopard (Uncia uncia, Schreber 1775). International Pedigree Book of Snow Leopards, vol. 2, pp. 137-158.

ROBERTS, T., 1977. The Mammals of Pakistan, Ernest Benn. The Mammals of Pakistan, London, vol. 26, pp. 361.

SCHALLER, G.B., 1976. Mountain mammals in Pakistan. Oryx, vol. 13, no. 4, pp. 351-356. http://dx.doi.org/10.1017/ S0030605300014071.

SCHALLER, G.B., 1977. Mountain monarchs. Wild sheep and goats of the Himalaya. Chicago, IL: University of Chicago Press.

SCHALLER, G.B., 1982. Stones of silence: Journeys in the Himalaya. Toronto: Bantam Books.

SEGAN, D.B., MURRAY, K.A. and WATSON, J.E., 2016. A global assessment of current and future biodiversity vulnerability to habitat loss-climate change interactions. Global Ecology and Conservation, vol. 5, pp. 12-21. http://dx.doi.org/10.1016/j. gecco.2015.11.002.

SHRESTHA, U.B., GAUTAM, S. and BAWA, K.S., 2012. Widespread climate change in the Himalayas and associated changes in local ecosystems. PLoS One, vol. 7, no. 5, pp. e36741. http:// dx.doi.org/10.1371/journal.pone.0036741. PMid:22615804.

SUBBA, S. A., 2012. Assessing the genetic status, distribution, prey selection and conservation issues of Himalayan wolf (Canis himalayensis) in Trans-Himalayan Dolpa, Nepal, Rufford Small Grants Foundation.

TELWALA, Y., BROOK, B.W., MANISH, K. and PANDIT, M.K., 2013. Climate-induced elevational range shifts and increase in plant species richness in a Himalayan biodiversity epicentre. PLoS One, vol. 8, no. 2, pp. e57103. http://dx.doi.org/10.1371/journal. pone.0057103. PMid:23437322.
THOMAS, C.D., CAMERON, A., GREEN, R.E., BAKKENES, M., BEAUMONT, L.J., COLLINGHAM, Y.C., ERASMUS, B.F.N., DE SIQUEIRA, M.F., GRAINGER, A., HANNAH, L., HUGHES, L., HUNTLEY, B., VAN JAARSVELD, A.S., MIDGLEY, G.F., MILES, L., ORTEGA-HUERTA, M.A., TOWNSEND PETERSON, A., PHILLIPS, O.L. and WILLIAMS, S.E., 2004. Extinction risk from climate change. Nature, vol. 427, no. 6970, pp. 145-148. http://dx.doi. org/10.1038/nature02121. PMid:14712274.

VALENTOVÁ, K. A., 2017. Abundance and threats to the survival of the snow leopard-a review. European Journal of Environmental Sciences, vol. 7, no. 1, pp. 73-93.

VAN VUUREN, D.P., EDMONDS, J., KAINUMA, M., RIAHI, K., THOMSON, A., HIBBARD, K., HURTT, G.C., KRAM, T., KREY, V., LAMARQUE, J.-F., MASUI, T., MEINSHAUSEN, M., NAKICENOVIC, N., SMITH, S.J. and ROSE, S.K., 2011. The representative concentration pathways: An overview. Climatic Change, vol. 109, no. 1-2, pp. 5-31. http://dx.doi.org/10.1007/s10584-011-0148-z.

WILLIAMS, J.W., JACKSON, S.T. and KUTZBACH, J.E., 2007. Projected distributions of novel and disappearing climates by $2100 \mathrm{AD}$. Proceedings of the National Academy of Sciences of the United States of America, vol. 104, no. 14, pp. 5738-5742. http://dx.doi. org/10.1073/pnas.0606292104. PMid:17389402.

WU, X., LU, Y., ZHOU, S., CHEN, L. and XU, B., 2016. Impact of climate change on human infectious diseases: empirical evidence and human adaptation. Environment International, vol. 86, pp. 14-23. http://dx.doi.org/10.1016/j.envint.2015.09.007. PMid:26479830.

XU, J., GRUMBINE, R.E., SHRESTHA, A., ERIKSSON, M., YANG, X., WANG, Y. and WILKES, A., 2009. The melting Himalayas: cascading effects of climate change on water, biodiversity, and livelihoods. Conservation Biology, vol. 23, no. 3, pp. 520-530. http://dx.doi. org/10.1111/j.1523-1739.2009.01237.x. PMid:22748090.

YAO, T., WANG, Y., LIU, S., PU, J., SHEN, Y. and LU, A., 2004. Recent glacial retreat in High Asia in China and its impact on water resource in Northwest China. Science in China. Series D, Earth Sciences, vol. 47, no. 12, pp. 1065-1075. http://dx.doi. org/10.1360/03yd0256. 